\title{
Reprise of: "Rethinking our Roles" Address to the Academy of International Business 2012 Annual Meeting - Opening Plenary
}

\author{
Ray Offenheiser, President, Oxfam America
}

GOOD MORNING. Thank you for the kind introduction and the warm welcome. And thank you, too, for the Academy of International Business President's Award.

I'm proud to accept it on behalf of my colleagues, who are fighting for social justice and economic empowerment in 110 countries with some 4,000 local non-profit partners. And who are seeking innovative ways to bend markets and market actors toward becoming forces for development and positive social change. I know they will be very gratified to know that their work has been recognized in this way. So again, I thank the Academy for honoring their work with this award.

We've come together here in Washington to think and talk about the changing relationships among businesses, governments, and NGOs in the global economy. And, clearly, these roles are changing. Dramatically.

Because of globalization, boundaries between the efforts and objectives of businesses, governments, and civil society are dissolving.

Segments of our economy sometimes defined in opposition to one another-some for profit, others for purpose - are under increasing pressure to align in common cause.

And during these last few years, we at Oxfam America have invested in both challenging corporate interests and behaviors and in catalyzing a remarkable convergence among the interests of businesses and the interests of NGOs like us around norms and more pro-poor business practices.

The consequences of this confluence are immense.

If done right and guided by new normative frameworks and business models, the potential for tangible progress and promise are substantial:

unprecedented growth in international commerce and business;

And new possibilities for economic empowerment and opportunity among the world's poor.

And, this afternoon, l'd like to talk about the forces and factors behind these phenomena - and about how we can work together to make the most of them.

\section{An Illustration: Extractive Industries}

The evolution of - and within - these changing relationships may best be illustrated by one particular industry, an industry long-noted for being combative rather than collaborative in the communities where it works. I'm talking about the extractive industries, which produce oil, coal, gas, and minerals.

Consider two snapshots from my career-still lifes of moments some three decades apart.

First, picture the late 1970s. There I was, clad in khaki, starting out as a field officer with the Inter-American Foundation in South America's Andean region. At that point, many extractive companies were in the beginning stages of exploration for natural resources in the Peruvian, Ecuadorian, and Colombian Amazons. Their approach was as direct as it was destructive: Bribe the governments. Secure a charter. Cut the trees. Build roads. Move locals out and colonists in. Dig a hole. Ignore the waste. And call in the army if you had a problem. These corporations were totally blind to the environmental damage they were causing. They were deaf to the concerns of native communities they were uprooting and alienating. But business was business. And this was the way that business - at least the mining business--was always done.

Now, fast-forward ... through the fall of the Berlin Wall, the rise of the iPhone, the collapse of the global economy. Fast-forward to just a few weeks ago, in $21^{\text {st }}$ century Brazil-where I attended a conference on mining in Belo Horizonte, Minas Gerais. Northwestern University's Kellogg School had organized this conversation with a number of leading industry players. The big and small mining companies were there along with the major suppliers: Caterpillar and Komatsu. And then Mark Cutifani, the President of AngloGold Ashanti - the world's third largest goldmining company - took to the podium and addressed the industry's emerging opportunities and obligations. He talked about, quote, "host communities," not drilling sites. He talked about creating, in his words, "shared value," about minding the health and well-being of employees, about respecting human rights. He spoke, at some length, about AngloGold Ashanti's pioneering approach to stakeholder "engagement." And he candidly acknowledged the hard lessons the company had learned by not always being on the right side of these issues in the past. Frankly, it was a presentation that Oxfam could have written. 
AngloGold Ashanti and many other companies are still in the business of extracting minerals, oil, and other natural resources. But the way they work - the way they conduct that core business - is under serious challenge all over the world and is albeit slowly changing from their early exploits and exploitation. Just to mention one "for instance," I have now joined a working group with Mark, with representatives from the industry and academy and others to try to develop a compelling vision for the 21 st century mining company.

And so, what these two snapshots represent - the first from the 1970s; the second from just a few weeks ago-is quite an extraordinary journey: A journey from an era when organizations like Oxfam and companies like AngloGold Ashanti were on opposite sides of the issues and the table ... to an era:

- when mining companies appreciate our role as a constructive critic;

- when they seek out our advice and counsel;

- and when they pilot consent agreements that explicitly spell out what indigenous people can expect in exchange for their resources.

\section{What's Going On?}

So, how can we explain this evolution? What was - and is - the rationale for companies in the extractive industries and elsewhere to start seeking out a new and more socially driven approach to doing business?

From Oxfam's perspective, we see three forces at work-a push, a pull, and a shifting sense of purpose and priorities.

First, the push. Today's global corporations have unprecedented power, but their very size makes them very big targets. Their brands and reputations face new risks in our interconnected Information Age. Just look at Mattel, which, in 2007, saw its stock value drop 18 percent in the wake of revelations there were high levels of lead in toys sourced from China. ${ }^{1}$ Or BP, whose market value plunged by more than one-third,
As you may be aware, Ethiopia grows some of the finest coffee beans in the world. At one point, Starbucks was selling gourmet Ethiopian beans for as much as $\$ 26$ a pound. Meanwhile, the farmers were getting paid less than $\$ 1.50$ a pound for their product. ${ }^{2}$ The Ethiopians realized the advantages of participating in securing rights to intellectual property so they decided to trademark and license their regional brands. But Starbucks, concerned about the impacts of this on their business model, tried to block them from exercising their economic rights. So Oxfam, after reaching out to corporate leadership to broker negotiations between Starbucks and the Ethiopian government, launched an advocacy campaign on the farmers' behalf. We didn't have a venti-sized budget. It felt like David vs. Goliath. But it challenged us to get creative with social media and civic activism. At a grassroots level, Oxfam worked with a coalition to organize members of the Ethiopian Diaspora, students, Starbucks employees, and our own supporter base. By the campaign's end, more than 100,000 people had gotten involved, the Wall Street Journal ran a front page article on the conflict, and Starbucks had learned a lot about the power of YouTube to shape their brand value. Ultimately, Starbucks founder Howard Schultz invited the Ambassador of Ethiopia to Seattle. They resolved the issue, and in fact, they signed a significant marketing, distribution, and licensing agreement that could be a model for other cases like this, in other countries and other industries that are part of the global fair trade movement. Two years of work capped with a victory is today benefiting millions of coffee growing families in Ethiopia. (By the way... you might be amused to know that at the end of this process, we both commissioned independent reviews of this whole experience that we shared with each other. Today, we are lobbying with Starbucks government affairs representatives on climate change and other development issues.)

And, although Starbucks had to be pushed to the table, the outcome reflected a shift in their thinking - and a recognition of the opportunity at hand, or what I would call the pull. In a world of global supply chains, companies like Starbucks have to make sure that suppliers can produce and deliver volume over the long-term. They need to think about local suppliers' personal welfare-their health, their education, their security.

And they're becoming more mindful of treating their local producers fairly so those local producers can become happy local consumers.

In our global economy, corporations see windfall opportunities to do busi-

and its brand value by more than $\$ 2$ billion, in the aftermath of the Deepwater Horizon explosion in the Gulf of Mexico. BP also felt its own kind of pain at the pump, when some of its gas stations reported sales losses of up to 40 percent in the months after the disaster. Or Starbucks, which found itself in proverbial hot water in 2006 when it resisted the efforts of Ethiopian farmers to trademark their coffees. ness-both harvesting raw materials from resource-rich places in the global south and selling products to billions of potential new purchasers who live in these same developing economies.

Just think about the continent of Africa, home to some of the world's fastest growing markets. ${ }^{3}$ Some 400 million of the world's poorest peo-

continued on page 20 
continued from page 19

ple live on the land. But that land itself represents 60 percent of the world's undeveloped arable soil. Underground, the continent's extractive sector was worth $\$ 246$ billion in 2009, according to the ONE Campaign. That's six times more than the total amount that its 47 countries accepted in development aid. ${ }^{4}$ Paul Collier, the Cambridge University development economist, in a panel in this town two weeks ago, predicted that over a trillion dollars will be extracted from Africa in the form of oil and minerals over the next decade and how the revenue from this windfall is used may be the biggest challenge and opportunity that African nations and the development community face over the next two decades. In short, Africa is a bonanza opportunity - as is much of the developing world - and countries and companies are responding accordingly by reevaluating all aspects of their supply chains and seeking to make them more reliable, resilient, and sustainable. Just last week the International Council of Mining and Minerals, the mining industry trade association released a report entitled: Human Rights, Social Development and the Mining and Minerals Industry. These are topics that it would have been unthinkable for the sector to be discussing so publicly even 5 years ago.

Take PepsiCo's "Performance with Purpose" initiative, and the company's work in India, as an example. Because Pepsi develops its line of beverages using water, the company is actively putting programs in place that give more water back to society than it uses in its manufacturing and bottling processes. Pepsi calls this a "positive water balance." As PepsiCo CEO Indra Nooyi says, this isn't charity. It's about Pepsi securing the social license to operate their plants and sell their soft drinks in markets like India, home to more than a billion potential new customers. It's the cost of doing business - and building a business that they hope will be even more profitable in years to come.

So, I talked about the push and pull that are bringing businesses and NGOs like Oxfam together. Finally, there's what I call the shift in companies' sense of purpose and priorities. When you think about what business wants - they're looking for new markets. They need calm political environments in which to invest. They want predictability. But as a foundation for these things, you need a social contract between a state and its citizens - a social contract that is respected, and believed in, and delivered on. And when you look around the world today, including here in the U.S., you see that social contract coming apart. The 99 percent are under serious pressure, social safety nets are being challenged and shredded, and that is creating profound pressure on civil order. Which means it's no longer just organizations like Oxfam that worry about social ills.

Today, the World Economic Forum - the venerable headquarters of Davos Man - is focused on the very same challenges. In fact, if you flip through the WEF's 2011 Global Risks assessment, you'll see words and phrases like "resource volatility," supply-side scarcity," and "economic disparity and social fragmentation."

These are the concerns that are keeping global CEOs up at night. And while, a generation ago, corporate executives thought government was responsible for tackling these issues, now, increasingly, they believe that their businesses - that they, themselves - have an active role to play in encouraging and creating more democratic and inclusive economic outcomes with equitable, sustainable growth.

\section{Our Current Development Efforts: Necessary, Not Sufficient}

So, how can we support and accelerate these trends, and create a true win-win, where companies and citizens can prosper together in peaceful, stable, sustainable societies? I think it begins by moving the discussion from the premise that "all growth is good" to the more complex and constructive question: How can we achieve "good growth"? Inclusive growth? How can we allow more people to participate in global markets in a fair and meaningful way? I'm sure you're familiar with many of the approaches that businesses, philanthropists, and governments have promoted in recent years: bottom of the pyramid, social entrepreneurship, impact investing, shared value, corporate social responsibility. But so far, these market-based approaches have not delivered on their promise. Where markets have grown, the benefits have not trickled down, which has resulted in greater inequality. And where poor communities have been targeted, too often, the successes have not been scalable.

The reason connects to something development experts increasingly understand: That poverty is not fundamentally about the absence of public goods or growth, but rather about the presence of injustice and the persistence of marginalization. That's why Oxfam has moved away from poverty reduction strategies that depend on delivering services directly... and moved toward strategies that remove the barriers and obstacles that hold people back and limit their access to opportunity and pathways out of poverty. Give a man a fish, he eats for a day. Take down the walls separating him from the water and, well, you know the rest.

\section{The Alternative: Empowerment and Transparency}

As we see it, there are two key elements essential to the development enterprise, and to achieving the kind of good growth that benefits society and business alike.

First, we need to do a better job empowering the people we're trying to reach. Businesses call them workers and consumers. NGOs call them citizens and communities. And, with greater frequency, both businesses and NGOs believe that they should be involved in shaping solutions to their own problems. And more commonly today, we are both calling them stakeholders.

Take our EquiTABLE Food Initiative_-an alliance among businesses and NGOs that's leading the way to fairer, safer, and more sustainable produce at big retailers like Costco. Recent studies show that socially conscious consumers make up 40 percent of the U.S. market. So through 
our coalition, we've created a voluntary certification system. If companies are good stewards of labor, food safety, and the environment, then consumers will know about it, and - through their purchasing decisions - can reward companies that do right by their workers. It's a great incentive for companies to help make our food system better for everyone. So, empowerment_-giving people agency and voice-is a critical part of the equation. gagement on the ground. In our negotiations with Coke, we insisted that the research be people-centered, that the process be participatory, and that the report's public release be followed by stakeholder events in each country.

We believe the report has paved the way for greater transparency around these issues going forward. Already, the companies and stakeholders are in discussion around new initiatives and changed practices.

\section{(s) When governments and businesses make deals, the people affected by them ought to know what those deals are.}

\section{Call to Action: Here's How You Can Help}

So, we're cautiously optimistic about the prospects for greater collaboration among NGOs and corporations. And I'm here to ask you, the academic community, to help us move this agenda for change. There are many ways that you can contribute-but let me suggest three. First, make it your mis-

The other essential aspect is transparency. When governments and businesses make deals, the people affected by them ought to know what those deals are. One major legislative victory in the fight for transparency came as a component of the United States' Dodd-Frank financial reform law. Now, extractive companies are required to publish what they pay to overseas governments. Product by product. Project by project. Amazingly, the Newmont Mining Corporation, one of the most forward thinking of the major global mining enterprises, joined us in lobbying for this new measure. We hope that other companies will follow Newmont's lead.

For Oxfam's part, another way we've been promoting transparency in partnership with businesses is through our Poverty Footprint studies-reports that analyze the full range of impacts that multinational corporations have on poor communities and then provide a platform for engagement around those impacts for Oxfam as well as other stakeholder groups. We conducted the first such footprint study in partnership with Unilever Indonesia. Together, we unpacked, inventoried, and scrutinized the company's investment policies, the employment its operations supported, and its impact in the marketplace. We also disected Unilever's value-chain - from supply to distribution - through in-depth conversation with soya bean and sugar farmers, factory workers, rural villagers, drivers and traders, and even government officials. What we learned is that while workers on Unilever's payroll were treated relatively well, the company needed to improve working conditions among sub-contracted staff. We also learned that the Poverty Footprint Methodology is a powerful tool for all kinds of applications.

Last fall, we released a similar Poverty Footprint Study with Coca-Cola and their bottler SABMiller. We knew we took a risk in co-branding such a study. We knewthat it might look like we were compromising our integrity. But we believed that working with the companies, we'd be guaranteed greater access, more nuanced understanding of power dynamics in the supply chain, and more opportunity to promote en- sion to educate a new kind of business leader. Talk and teach about $21^{\text {st }}$ century ethics, because companies will need to think and act more ethically to prosper in the $21^{\text {st }}$ century markets. And help tomorrow's executives develop the skills to relate with stakeholders throughout their society - from policy makers to industry colleagues and competitors to the public to NGOs. The $21^{\text {st }}$ century executive needs to be a strong relationship manager across all varieties of social, economic and political boundaries. Second, conduct research that makes the business case for sustainable practices, for empowerment, and for transparency. It won't be enough for a few corporate pioneers to test out their experiments. We need proven methodologies for others to learn from, to follow, adapt, and apply. To borrow Malcolm Gladwell's challenge, we don't need one or two "tipping point" experiences, we need scores of them. Third, business schools could help scale up the concept of Poverty Footprint Studies - and other forms of scholarship that measure the social and human rights impacts of business practices.

As expert academics, you can offer legitimacy and impartiality to the reports while providing students with hands-on, real-life opportunities to see how value chains impact poverty and to explore what companies can do to address social challenges within their business and the communities where they operate.

\section{Conclusion}

Which brings me full circle - to the mines of high Andes, not far from the indigenous communities where I began my career, and to a story that's now become a case study for the Harvard Business Review. A dozen years ago, the world turned its attention to Peru and watched with horror. What people saw at places like BHP Billiton's massive Tintaya Copper Mine were corrupt land deals, violent forced evictions, vile air and water pollution, all met with protests and upheaval. This was no continued on page 22 
continued from page 21

small matter for the planet's second largest copper-producing nation. So, Oxfam got involved at the request of local community organizations. We conducted an investigation of the communities' concerns and presented our findings to BHP's leadership. We educated company executives. We helped to open dialogue between the company and indigenous peoples. We joined in establishing commissions charged with resolving disputes over land, human rights, the environment, and sustainable development. And many displaced residents earned some compensation for their losses. They even received development dollars for a new hospital.

Now, my point in sharing this story is not to hold it up as a complete success. It wasn't one. Too many people lost too much —on both sides of the conflict. My point in recounting this episode is that it should be a cautionary tale for all of us. Today - together-we must rethink the roles of business, government, and NGOs in the global economy. If we don't, then we'll all suffer-not just the communities that have long been poor and vulnerable, but also the companies that rely on their resources, their labor, and their consumption. These are the new facts of business. But if we start by understanding that-with increasing frequency — businesses, governments, and NGOs can share the same aims and aspirations, then we can continue building a world that's more just and equitable for the poor-and, yes, more profitable for the private sector simultaneously. For my money, I think that's a vision of equitable growth and shared progress that we all can be excited about bringing to life. And with your help, that's exactly what we'll keep doing.

Thank you all very much.

\section{Endnotes}

1 http://www.pwc.com/en_GX/gx/operations-consulting-services/pdf/ value-sustainable-procurement-practices.pdf.

2 These numbers come from Ray's speech at Notre Dame some years ago.

3 World Economic Forum on Africa, "Meeting Overview," http://www3. weforum.org/docs/AF12/WEF_AF12_MeetingOverview.pdf.

4 Bono, "The Resource Miracle," TIME Magazine, 5/28/12, http://www.time. com/time/magazine/article/0,9171,2115044,00.html. Also see: http:// www.guardian.co.uk/business/2012/feb/16/bill-gates-pressures-obamaenergy-legislation. 